\title{
Evaluating the Impact of Wetland Health on Wildlife Health by Soil and Water Quality Analysis
}

\author{
Devendra Podhade ${ }^{1 *}$, S. B. Lal ${ }^{1}$, Somesh Singh ${ }^{2}$, B. Mehera ${ }^{1}$, \\ Neelam Khare ${ }^{1}$ and Abhishek James ${ }^{1}$ \\ ${ }^{1}$ College of Forestry, SHUATS, Prayagraj-211007, India \\ ${ }^{2}$ School of Wildlife Forensic and Health, NDVSU, Jabalpur-482001, India \\ *Corresponding author
}

\section{A B S T R A C T}

\begin{tabular}{|l|}
\hline Ke y w or d s \\
$\begin{array}{l}\text { Wetlands, Soil } \\
\text { Analysis, Water } \\
\text { Analysis, Narmada } \\
\text { Valley, Jabalpur }\end{array}$ \\
\hline Article Info \\
\hline $\begin{array}{l}\text { Accepted: } \\
10 \text { August } 2020 \\
\text { Available Online: } \\
10 \text { September } 2020\end{array}$ \\
\hline
\end{tabular}

\section{Introduction}

India has totally 67,429 wetlands, covering an area of about 4.1 million hectares (MoEF, 1990). Out of these, 2,175 are natural and 65,254, made man. Wetlands in India (excluding rivers), account for $18.4 \%$ of the country's geographic area, of which $70 \%$ is under paddy cultivation. Wetlands are important natural resources and ecosystems in nature, that play an important role in maintaining ecological balance, hence they are also called "the kidneys of the Earth" (Paul, 2000; Holland, 1996). They are also often called as biodiversity "hotspots" (Reid et al., 2005). They comprise of the most creative flora and fauna with a wide array of goods and services. These ecosystems serve as life support in many ways and provide unique habitat for a variety of organisms including migratory birds for food and shelter. Wetlands also support biological diversity in many ways and help to maintain dependent numerous species of flora as well as fauna.

Wildlife health is one of the main constituent in wetland ecosystem which is dependent on soil and water quality. The urbanization and 
growing human populations and settlements led to encroachment of wetlands for bathing, agriculture, fishing, cultivation etc. that lead to displacements of natural wildlife. Habitat reduction along with destruction leads to fauna seeking alternate sources. Narmada valley in Jabalpur encompasses number of wetlands in Madhya Pradesh which serve as ideal habitat for dependent species. However, many of the water bodies are struggling for their existence due to soil and water pollution which supports several wetland dependent species and such losses in habitat have threatened the diversity of wetland ecosystem.

Looking to these facts the research was carried out to evaluate the impact of wetland health on wildlife health by soil and water quality analysis in wetlands of Jabalpur along Narmada Valley.

\section{Materials and Methods}

Geographically, Jabalpur city is situated in the Mahakoshal region located at the center of India in the state of Madhya Pradesh at $23.1815^{\circ} \mathrm{N}$ latitude and $79.9864^{\circ} \mathrm{E}$ longitude (Plate. No.1) for present study the wetlands viz. Balsagar lake, Gangasagar Lake, Gwarighat (Narmada river bank), Mahanadda lake, Sangram sagar lake and Ranital Lake were chosen (Plate. No. 2 and 3).

The soil samples $(0-15 \mathrm{~cm})$ were collected from the field from six different location i.e. S1-S6 of each wetland (Plate. No. 4). The soil samples were air dried and crushed with wooden pestle and mortar and sieved through $2 \mathrm{~mm}$ sieve. Various parameters of soil samples were processed by method prescribed in the Table No.1.

Samples were collected from 5-8 cm depth in acid polyethylene bottles of $1 \mathrm{~L}$ capacity and properly labelled immediately after collection. The physiochemical analysis of the water samples of wetlands was done as per method described in the table No. 2.

\section{Results and Discussion}

As soil harbours biodiversity, it is necessary to know the health status of soil status of wetland. The parameters assessed are shown in the Table No. 3.

$\mathrm{pH}$ can affect the availability of nutrient in the soil. Mean $\mathrm{pH}$ of soil measured from six different locations was found maximum 7.43 at Ranital which may be due to high salt concentration in soils which was also reported by Shrivastav (1996) and Mendhe (1997). Mahajan and Billlore (2014) found $\mathrm{pH} 8.92$ in the Naghchoon pond soil of Madhya Pradesh which was alkaline in nature with higher $\mathrm{pH}$ level than normal range

Electrical Conductivity (EC) is the soil salinity or concentration of salt in soil. Mean EC was noticed maximum 0.29 at Ranital and minimum (0.16) at Sangramsagar. Mahajan and Billore (2014) also recorded slightly higher EC in the Naghchoon pond soil of Madhya Pradesh.

Organic carbon is an influential factor which increases the availability of iron and boron but decreases the availability of manganese, zinc and copper to plant. Mean Organic carbon (OC) was maximum at Ranital 1.41 and minimum at Gangasagar 0.88. The low organic carbon can be due to mixing of sewage water into the Lake.

Nitrogen is one important macronutrient and constituent of soil having chlorophyll. The overall mean value of Nitrogen $(\mathrm{N})$ was found in water was maximum at Ranital i.e. 365.33 $\mathrm{kg} / \mathrm{hec}$ and minimum at Gangasagar 312.5 kg/hec (Fig. 1 and 2; Table 4). 
Table.1 Various parameters for soil quality analysis

\begin{tabular}{|c|l|l|}
\hline $\begin{array}{c}\text { S. } \\
\text { No. }\end{array}$ & \multicolumn{1}{|c|}{ Properties } & Reference and the method of analysis \\
\hline (i) & Organic carbon $(\%)$ & Walkley and Black (1947) \\
\hline (ii) & Available nitrogen $\left(\mathrm{kg} \mathrm{ha}^{-1}\right)$ & $\begin{array}{l}\text { Alkaline KMnO } \mathbf{K}_{4} \text { method (Subbiah and } \\
\text { Asija, 1956) }\end{array}$ \\
\hline (iii) & Available phosphorus $\left(\mathrm{P}_{2} \mathrm{O}_{5} \mathrm{~kg} \mathrm{ha}^{-1}\right)$ & Olsen's method (Olsen et al., 1954) \\
\hline (iv) & Available potassium $\left(\mathrm{K}_{2} \mathrm{O} \mathrm{kg} \mathrm{ha}^{-1}\right)$ & Flame photometer (Richards, 1968) \\
\hline (v) & Electrical conductivity $\left(\mathrm{dSm}^{-1}\right.$ at $\left.25^{0} \mathrm{C}\right)$ & Conductivity bridge (Richards, 1968) \\
\hline (vi) & pH (1:2.5 soil water ratio) & pH meter (Piper, 1950) \\
\hline
\end{tabular}

Table.2 Parameters for physio-chemical analysis of water samples

\begin{tabular}{|c|c|c|c|}
\hline S. No. & Properties & Method of analysis & Reference \\
\hline A. & \multicolumn{2}{|c|}{ Physical composition } & \\
\hline (i) & Temperature & & \\
\hline (ii) & Turbidity & Nephelometric method & APHA (1998) \\
\hline (iii) & $\begin{array}{l}\text { Specific } \\
\text { Conductivity }\end{array}$ & Laboratory method & APHA (1998) \\
\hline B. & \multicolumn{2}{|c|}{ Chemical properties } & \\
\hline (i) & $\mathrm{pH}$ & Electrometric method & APHA (1998) \\
\hline (ii) & Total Alkalinity & Titration method & APHA (1998) \\
\hline (iii) & Total Hardness & Titration (EDTA method) & $\begin{array}{l}\text { Trivedi and Goel } \\
\text { (1986) }\end{array}$ \\
\hline (iv) & Calcium Hardness & Titration (EDTA method) & $\begin{array}{l}\text { Trivedi and Goel } \\
\text { (1986) }\end{array}$ \\
\hline (v) & $\begin{array}{l}\text { Magnesium } \\
\text { Hardness }\end{array}$ & Titration (EDTA method) & $\begin{array}{l}\text { Trivedi and Goel } \\
\text { (1986) }\end{array}$ \\
\hline (vi) & Chloride & Argentometric method & APHA (1998) \\
\hline (vii) & Total solids & Total solids dried at $103-105{ }^{\circ} \mathrm{C}$ & APHA (1998) \\
\hline (viii) & Dissolved solids & $\begin{array}{l}\text { Total dissolved solids dried at } \\
180^{\circ} \mathrm{C}\end{array}$ & APHA (1998) \\
\hline (ix) & Suspended solids & $\begin{array}{l}\text { Total suspended solids dried at } \\
103-105^{\circ} \mathrm{C}\end{array}$ & APHA (1998) \\
\hline (x) & $\begin{array}{l}\text { Nitrate } \\
\text { Nitrogen }\left(\mathrm{NO}_{3}\right)\end{array}$ & $\begin{array}{l}\text { Ultraviolet Spectrophotometric } \\
\text { Screening method }\end{array}$ & APHA (1998) \\
\hline (xi) & $\begin{array}{l}\text { Dissolved oxygen } \\
\text { (D.O) }\end{array}$ & Azide modification & APHA (1998) \\
\hline (xii) & $\begin{array}{l}\text { BOD (3 days at } 27 \\
\left.{ }^{\circ} \mathrm{C}\right)\end{array}$ & Bioassay method & APHA (1998) \\
\hline (xiii) & COD & Open Reflux method & APHA (1998) \\
\hline
\end{tabular}


Table.3 Mean values of soil samples at different wetlands of Jabalpur

\begin{tabular}{|c|c|c|c|c|c|c|c|c|c|}
\hline \multirow[t]{2}{*}{ S. No. } & \multirow[t]{2}{*}{ Parameters } & \multirow[t]{2}{*}{ Unit } & \multicolumn{6}{|c|}{ Mean Values } & \multirow[t]{2}{*}{ Average } \\
\hline & & & Gwarighat & Ranital & Gangasagar & Mahanadda & Balsagar & Sangramsagar & \\
\hline 1. & $\mathrm{pH}$ & & 7.13 & 7.43 & 7.34 & 7.27 & 7.38 & 7.27 & 7.30 \\
\hline 2. & $\mathrm{EC}$ & conductivity-meter & 0.19 & 0.29 & 0.17 & 0.17 & 0.17 & 0.16 & 0.19 \\
\hline 3. & $\mathrm{OC}$ & $\mathrm{gm} / \mathrm{kg}$ & 1.01 & 1.41 & 0.88 & 0.94 & 0.94 & 1.11 & 1.05 \\
\hline 4. & $\mathrm{~N}$ & $\mathrm{~kg} / \mathrm{hec}$ & 346.5 & 365.33 & 312.5 & 330.83 & 326.5 & 346.16 & 337.97 \\
\hline 5. & $\mathrm{P}$ & $\mathrm{kg} / \mathrm{hec}$ & 17.44 & 19.89 & 16.48 & 18.13 & 15.05 & 15.16 & 17.03 \\
\hline 6. & $\mathrm{~K}$ & $\mathrm{~kg} / \mathrm{hec}$ & 344 & 368.33 & 360.5 & 365 & 344 & 357.16 & 356.50 \\
\hline
\end{tabular}

Mean values of soil samples at different wetlands of Jabalpur showed that following values of different parameters

Table.4 Mean values of water samples from different wetlands of Jabalpur

\begin{tabular}{|c|c|c|c|c|c|c|c|c|c|}
\hline \multirow[t]{2}{*}{ Sr. No. } & \multirow[t]{2}{*}{ Parameters } & \multirow[t]{2}{*}{ Unit } & \multicolumn{6}{|c|}{ Values } & \multirow[t]{2}{*}{ Average } \\
\hline & & & Gwarighat & Ranital & Gangasagar & Mahanadda & Balsagar & Sangramsagar & \\
\hline 1. & Temperature & ${ }^{0} \mathrm{C}$ & 28.35 & 27.62 & 28.33 & 28.40 & 28.72 & 27.40 & 28.14 \\
\hline 2. & Turbidity & NTU & 7.53 & 27.10 & 22.17 & 31.60 & 18.47 & 24.00 & 21.81 \\
\hline 3. & Specific Conductivity & umhos/cm & 163.63 & 397.17 & 277.50 & 330.83 & 259.17 & 316.33 & 290.77 \\
\hline 4. & $\mathrm{pH}$ & & 7.41 & 7.79 & 7.92 & 8.08 & 7.92 & 7.72 & 7.81 \\
\hline 5. & Total Alkalinity & $\mathrm{mg} / \mathrm{l}$ & 80.50 & 169.17 & 143.00 & 203.67 & 172.00 & 170.67 & 156.50 \\
\hline 6. & Total Hardness & $\mathrm{mg} / \mathrm{l}$ & 105.00 & 173.33 & 127.00 & 196.67 & 141.17 & 174.33 & 152.92 \\
\hline 7. & Calcium Hardness & $\mathrm{mg} / \mathrm{l}$ & 70.33 & 117.17 & 83.50 & 131.33 & 115.17 & 116.17 & 105.61 \\
\hline 8. & Magnesium Hardness & $\mathrm{mg} / \mathrm{l}$ & 34.66 & 56.17 & 44.33 & 65.33 & 57.50 & 58.17 & 52.69 \\
\hline 9. & Chloride & $\mathrm{mg} / \mathrm{l}$ & 27.73 & 34.19 & 26.09 & 33.87 & 26.33 & 29.64 & 29.64 \\
\hline 10. & Total solids & $\mathrm{mg} / \mathrm{l}$ & 201.33 & 385.00 & 291.17 & 332.17 & 233.33 & 220.00 & 277.17 \\
\hline 11. & Dissolved solids & $\mathrm{mg} / \mathrm{l}$ & 170.16 & 343.00 & 261.00 & 252.83 & 209.33 & 197.67 & 239.00 \\
\hline 12. & Suspended solids & $\mathrm{mg} / \mathrm{l}$ & 31.16 & 42.00 & 26.83 & 46.00 & 24.17 & 22.33 & 32.08 \\
\hline 13. & Nitrate Nitrogen & $\mathrm{mg} / \mathrm{l}$ & 1.18 & 3.23 & 2.33 & 2.66 & 1.64 & 2.44 & 2.25 \\
\hline 14. & Dissolved oxygen & $\mathrm{mg} / \mathrm{l}$ & 7.71 & 4.86 & 4.21 & 5.52 & 6.83 & 6.07 & 5.87 \\
\hline 15. & BOD $\left(3\right.$ days at $\left.27^{\circ} \mathrm{C}\right)$ & $\mathrm{mg} / \mathrm{l}$ & 1.63 & 13.34 & 9.53 & 13.85 & 8.72 & 11.63 & 9.78 \\
\hline 16. & $\mathrm{COD}$ & $\mathrm{mg} / \mathrm{l}$ & 11.13 & 38.47 & 31.40 & 31.33 & 22.10 & 28.13 & 27.09 \\
\hline
\end{tabular}


Fig.1 Graphical representation of Mean values of water samples different wetlands of Jabalpur

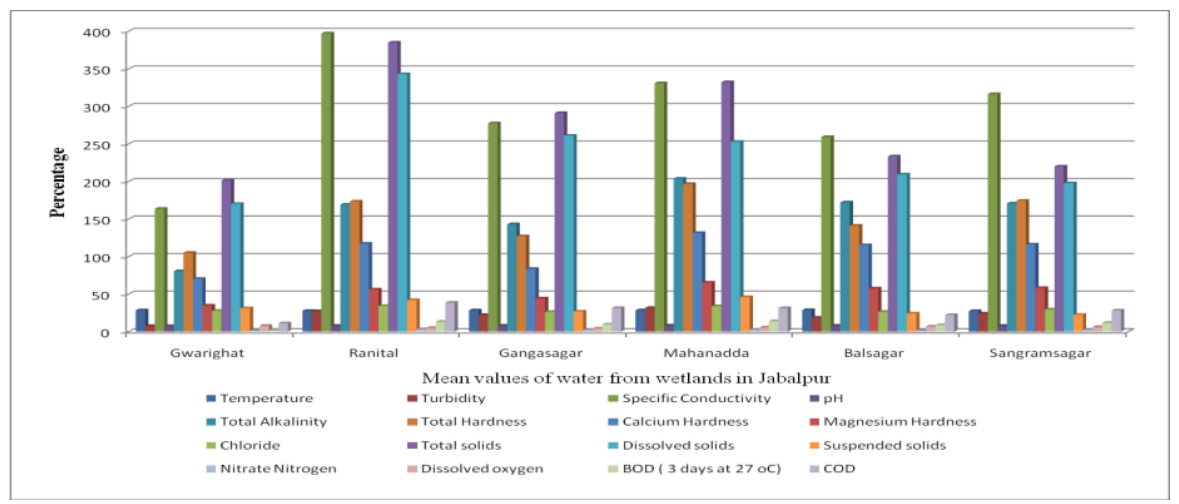

Fig.2 Graphical representation of mean values of soil quality parameters in different wetlands of Jabalpur

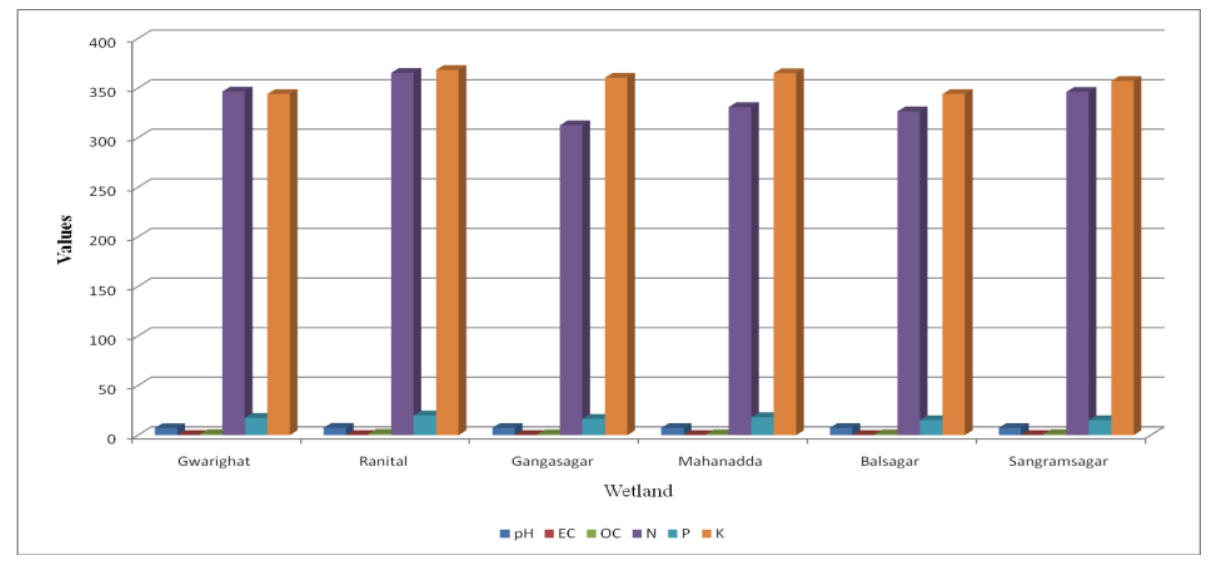

Plate.1 Location map of Jabalpur M.P., India

\section{INDIA}

Madhya Pradesh

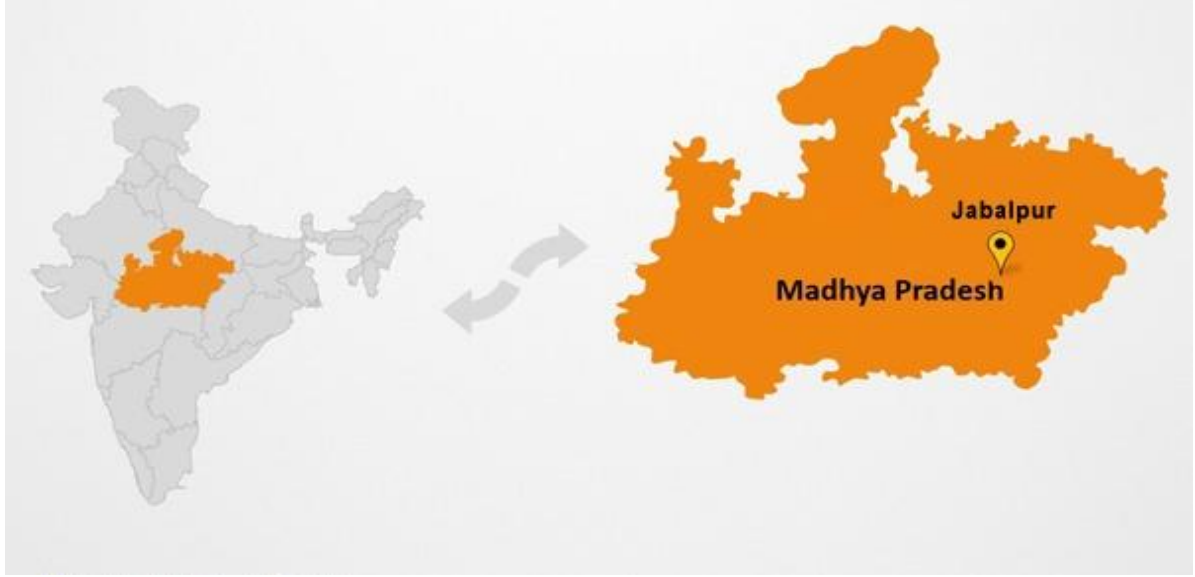




\section{Plate.2 Map of wetlands of in Index}

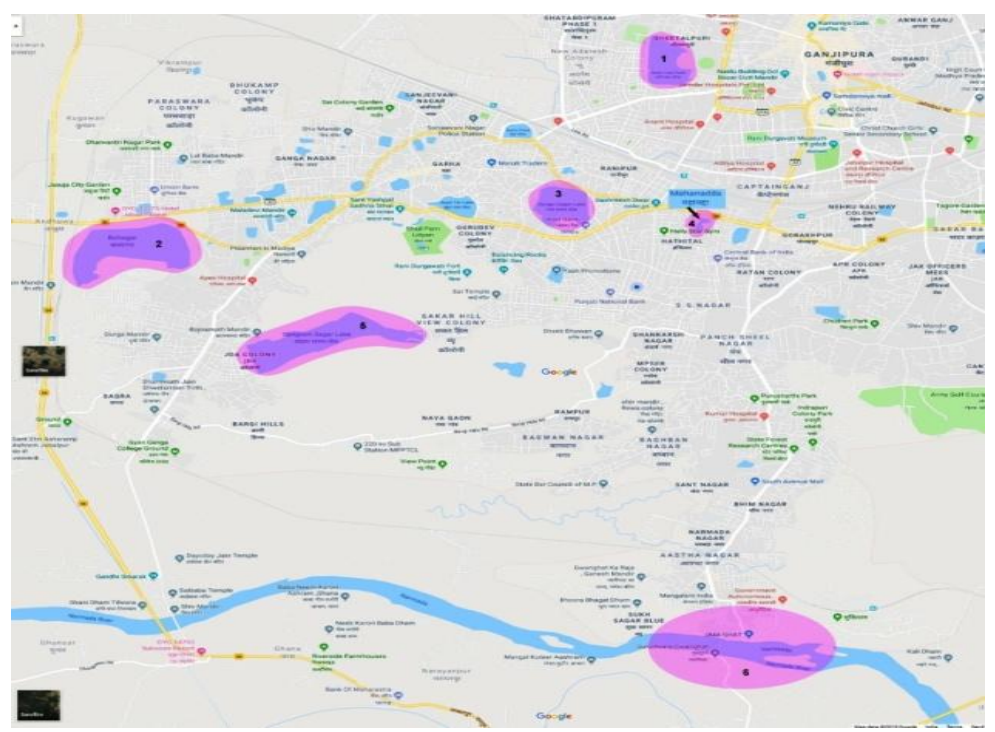

Index-

1-Rani Talab; 2-Balsagar Talab;

3- Gangasagar Talab; 4- Mahanadda

Talab; 5- Sagramsagar

Talab; 6 -Gwarighat (Narmada

Plate.3 Six wetlands of Jabalpur

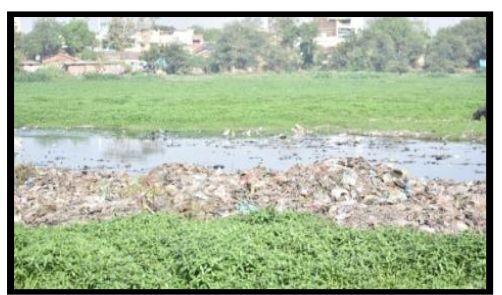

Ranital Talab

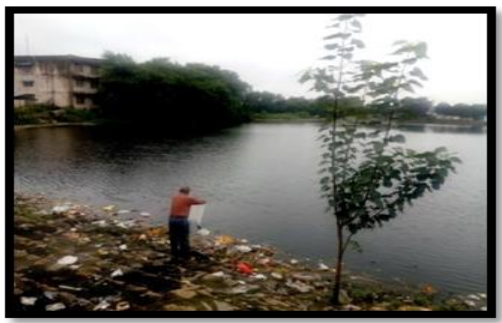

Mahanadda Talab

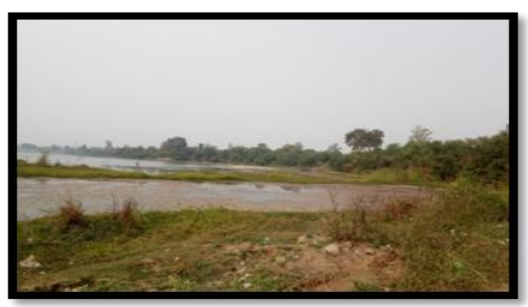

Balsagar Talab

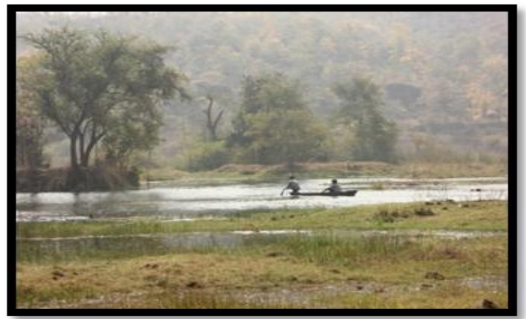

Sangramsagar Talab

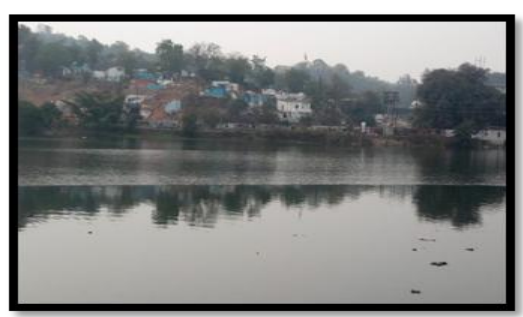

Gangasagar Talab

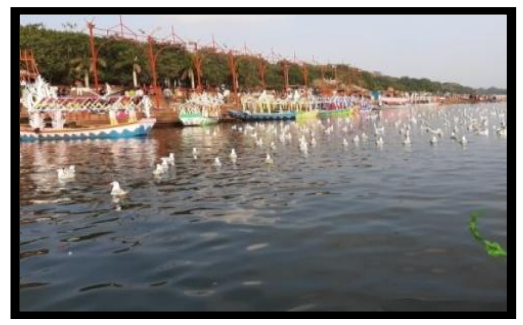

Gwarighat 
Plate 4 Collection of Soil samples from wetlands

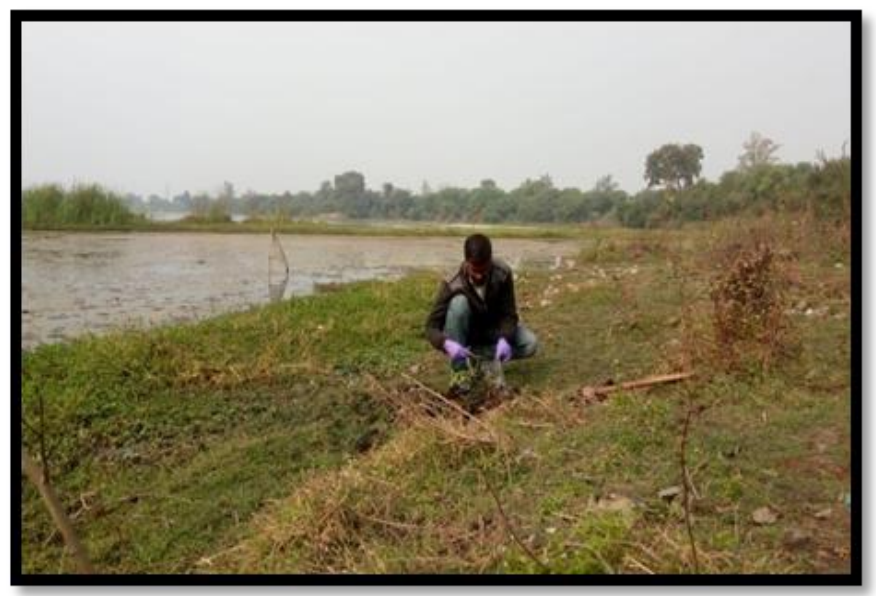

Phosporus is macronutrient in the soil of wetland which plays a significant role in eutrophication process as per Wang et al., (2003). Available mean phosphorus (P) was found maximum at Ranital i.e. $19.89 \mathrm{~kg} / \mathrm{hec}$ and minimum at Balsagar $15.05 \mathrm{~kg} / \mathrm{hec}$. Higher phosphorus content of soil represent high vegetation diversity replacing original faunal habitat which was also reported by Fauzie et al., (2015) and Gairola et al., (2012). Correll (1998) reported an excessive concentration of $\mathrm{P}$ to be the most common cause of eutrophication in freshwater lakes, reservoir and streams.

Potassium is third important macronutrient of the soil and essential for photosynthesis, protein synthesis, starch formation and for the translocation of sugars (Rai et al., 2011). Available mean potassium (K) was found maximum at i.e. Ranital $(368.33 \mathrm{~kg} / \mathrm{hec})$ and minimum at Gwarighat (344 $\mathrm{kg} / \mathrm{hec})$ and Balsagar $(344 \mathrm{~kg} / \mathrm{hec})$. Higher $\mathrm{K}$ values was due contamination of lake water with sewage water which was also reported by Beddesha $e t$ al., (1997).

The concentration of nitrogen, phosphorus and potassium is high due to the anthropogenic activities like domestic sewage, converting the ponds into agricultural areas, accumulation of heavy metals and hydrocarbons etc., in and around Ranital lake similar findings were reported by Manimegali and Sukanya, (2014) in the soil of Muthannan Kulam Wetland, Coimbatore. The high level of soil pollution at Ranital leads to migration of most of the avifauna as compared to other lakes.

Mean values of water samples showed very little variation in the water temperature of wetlands with maximum $28.72^{\circ} \mathrm{C}$ at Balsagar and minimum $27.40^{\circ} \mathrm{C}$ at Sangramsagar. The temperature of hanuman tal was $27.7^{\circ} \mathrm{C}$ and that of Roberston lake was $27.9^{\circ} \mathrm{C}$ as reported by Dixit and Shrivastav (2013) whereas Shrivastav and Thakur (2018) found temperature of five lakes in Jabalpur (M.P.) (i.e. Bal sager, Sangram sager, Supatal, Devtal and Ganga sager) within $18-25^{\circ} \mathrm{C}$.

The maximum mean turbidity i.e. 31.60 NTU was reported at Mahanadda and minimum at Gwarighat (7.53 NTU) as pollutants like clay, organic and inorganic matter and other microscopic organism which came with the effluents from nearby drains made water highly turbid in maximum lakes, which affected light penetration. Turbidity of Gwarighat was found within the permissible limits i.e. 7.53 NTU because of flowing water whereas Jain et al., (2017) reported turbidity ranged from 3.9 to $8.2 \mathrm{NTU}$ at river Narmada 
in Jabalpur using phyio-chemical method. Gupta et al., (2017) found turbidity in the range of 0.01-178.25 NTU in river water of Narmada. The high value of turbidity was because of the sediments from the nearby areas and due to turbulent flow which stirred up the non living matter like silt and sand at the bottom of the river.

Mean specific conductivity was noticed maximum at Ranital (397.17) and minimum at Gwarighat (163.63). Maximum specific conductivity was found at Ranital 397.17 as sewage waste was coming from surrounding area similar finding was reported by Shrivastav and Thakur (2018) who found values of conductivity in the range of 725 to 1032 mhos. Saini and Dube (2017) conducted study of water quality of Narmada river of Jabalpur region at five ghats namely Lamhetaghat (S-1), Laxminarayan Ghat (S2), Gograghat (S-3), Saraswati Ghat (S-4), Bhedaghat (S-5) and found annual conductivity of S1: -230, S-2:- 253.91. S-3: 229.91, S-4:- 248.75 and S-5: - 247.66.

$\mathrm{pH}$ of water was found maximum at Mahanadda i.e. 8.08 and minimum at Gwarighat 7.41 which was alkaline in nature. Rise in $\mathrm{pH}$ level of Mahanadda is because of mixing of sewage water into the lake which leads to loss of habitat and nestling sites of many avifaunal families like Threskiornithidae and Ciconiidae from that lake. Saini and Dube (2017) assessed the water quality of river Narmada in Jabalpur from Lamhetaghat and Bhedaghat and found $\mathrm{pH}$ value observed at Lamhetaghat was 8.7 and Bhedaghat was 7.28 and main source contributing to the pollution was garbage through nearby villages, ritual reasons and cowdung.

The Mean Total Alkalinity of water was reported maximum at Mahanadda i.e. 203.67 $\mathrm{mg} / \mathrm{l}$ and minimum at Gwarighat $80.50 \mathrm{mg} / \mathrm{l}$.
High level of total alkalinity leads to migration of many vulnerable and near threatened species from Mahanadda lakes. Saini and Dube (2017) analyzed water samples at two different sampling stations i.e. Lamhetaghat and Bhedaghat of river Narmada in Jabalpur and found total alkalinity at Lametaghat was $211.3 \mathrm{mg} / \mathrm{l}$ and at Bhedaghat it was $218.25 \mathrm{mg} / \mathrm{l}$

Mean Total Hardness was recorded maximum at Mahanadda $196.67 \mathrm{mg} / \mathrm{l}$ and minimum at Gwarighat $105.00 \mathrm{mg} / \mathrm{l}$. Higher hardness values in Mahanadda was due to the regular addition of sewage waste from surrounding area which leads to loss of many avian species from that habitat. Shrivastav and Thakur (2018) investigated total hardness of five lakes in Jabalpur and found values of Supatal at maximum $200 \mathrm{mg} / \mathrm{l}$ and at Sangram Sagar it was minimum i.e. $92 \mathrm{mg}$.

Chloride is an important indicator of water pollution. Mean Chloride was maximum at Ranital $34.19 \mathrm{mg} / \mathrm{l}$ and minimum at Gangasagar $26.09 \mathrm{mg} / \mathrm{l}$. Chloride level was maximum at Ranital $(34.19 \mathrm{mg} / \mathrm{l})$ due to mixing of sewage waste in the lakes. Similar finding was reported by Shrivastav and Thakur (2018) who also found maximum value at Supatal lake $(120 \mathrm{mg} / \mathrm{l})$ due to the sewage waste coming from the surrounding area.

Mean Total Solids evaluated was found maximum at Ranital lake $385.00 \mathrm{mg} / \mathrm{l}$ and minimum at Gwarighat $201.33 \mathrm{mg} / \mathrm{l}$. Total solids was maximum at Ranital lake which leads to loss of nesting sites and habitat for many of the avian species. This was because of pollutants which came directly with the effluents from nearby drains which resembled with the finding of Verma and Akhtar (2015).

Mean Dissolved Oxygen (DO) is essential for all living organism in which maximum DO 
was noticed at Gwarighat $7.71 \mathrm{mg} / \mathrm{l}$ and minimum at Gangasagar $4.21 \mathrm{mg} / \mathrm{l}$. DO value of Ranital $4.86 \mathrm{mg} / \mathrm{l}$ and Gangasagar (4.21 $\mathrm{mg} / \mathrm{l})$ was very low that indicates deoxygenated water which lead to search for alternate habitat for many avian species. Gupta et al., (2017) found DO range from 2.4 to $7.8 \mathrm{mg} / \mathrm{l}$ from six sites (S1-S6) of Narmada river. Sites S1, S2, S3 and S4 have values less than the prescribed limit of $5 \mathrm{mg} / \mathrm{l}$ which showed these areas were highly deoxygenated and low DO concentration was due to waste discharges high in organic matter and nutrient near by the river site. Khadse et al., (2008) found DO in the rivers ranged between nil to 8.5 Absence of DO in Nag river in their study was due to its sewage content from Nagpur city.

Mean Biochemical Oxygen Demand (BOD) was noticed maximum at Mahanadda (13.85 $\mathrm{mg} / \mathrm{l})$ and minimum at Gwarighat $(1.63 \mathrm{mg} / \mathrm{l})$. Maximum BOD was due to mixing of drainage water to lake which leads to migration of many species from Mahanadda lake. High BOD was also recorded by Singh and Shrivastav (2015) at station-7 out of 12 stations of Narmada River which could be due to the influence of sewage.

Mean Chemical Oxygen Demand (COD) was found maximum at Ranital $(38.47 \mathrm{mg} / \mathrm{l})$ and minimum at Gwarighat (11.13 $\mathrm{mg} / \mathrm{l})$. The maximum COD level at Ranital $(38.47 \mathrm{mg} / \mathrm{l})$ indicated high level pollution in comparison to other lakes which leads to loss of habitat and nesting sites of the birds like open billed stork, lesser adjuvant stork and baya waver. Singh and Shrivastav (2015) analyzed water quality in 12 stations of Narmada River and found COD level varying from 10.4 to 46 $\mathrm{mg} / \mathrm{l}$. The high value of COD (46 mg/l) was observed due to direct mixing of the domestic sewage, detergents and industrial effluents in river Narmada.
Jabalpur is niche for around 36 ponds or lakes which form very good wetlands for the wildlife conservation. The human encroachment, destruction of habitat, expansion of agricultural lands and other anthropogenic factors are causing great loss to wetlands and wildlife harboring there. The management of wetlands should focus on prevention of immersion of religious wastes, pooja offerings and idols, ban on uses of polythene bags, fishing, brick making, sand mining and treatment of sewage and drainage before allowing in mainstream water for conservation of wetland dependent species. It is recommended that periodical study should be carried out to know effect of soil and water quality on health of wildlife of wetlands along Narmada Valley.

\section{Acknowledgement}

Authors are thankful to the Hon'ble ViceChancellor, SHUATS, Naini, Prayagraj and Dean, College of Forestry, SHUATS, Prayagraj for providing the necessary facilities to carry out the present study.

\section{References}

APHA(1998). Standard methods for the examination of water and waste water, $20^{\text {th }}$ edn. Washington, DC: American Public Association / American water works Association/ Water Environment Federation.

Baddesha, H.S., Chhabra, R.and Ghuman, B.S. (1997). Changes in soil chemical properties and plant nutrient content under eucalyptus irrigated with sewage water. J. Ind. Soc. of Soil Sci., 45(2): 358-362.

Correll, D. L. (1998). The Role of Phosphorus in the Eutrophication of Receiving Waters: A Review. J. Environ. OUAL. 27: 261-266.

Dixit, A. and Shrivastava, S. (2013). 
Assessment of Parameters of Water Quality Analysis of Hanumantal and Robertson Lake at Jabalpur (M.P.) Asian J. Res. Chem. 6(8): 752-754.

Fauzie, A. K., Khudsar, F. A. and Sreenivasa (2015). Analysis of Soil PhysicoChemical Properties in Various Sites at Yamuna Biodiversity Park, Delhi, India. Int. J. Innovative Res. Sci., Engg. Tech. 4(8): 7220-7228.

Gairola, S., Sharma, C. M., Ghildiyal, S. K. and Suyal, S, (2012). Chemical properties of soils in relation to forest composition in moist temperate valley slopes of Garhwal Himalaya, India. Environmentalist. 32(4): 512-523.

Gupta, N., Pandey, P. and Hussain, J. (2017). Effect of physicochemical and biological parameters on the quality of river water of Narmada, Madhya Pradesh, India. Water Sci. 31: 11-23.

Holland, M. M. (1996). Wetlands and environment gradients [G] Mulamoottil G., Warner B. G., McBean E A. Wetland Environment Gradients, Boundaries and Buffers. CRC Press Inc., pp. 112-131.

Jain, D., Rahi, D. C. and Verma, S. (2017). Physico-Chemical assessment of water quality of River Narmada in Jabalpur city area of Madhya Pradesh. Int. J. Res. Applied Sci. Engi. Tech. 5(2):80-83.

Khadse, G. K., Patni, P. M., Kelkar, P. S. and Devotta, S. (2008). Qualitative evaluation of Kanhan river and its tributaries flowing over central Indian plateau. Environmental Monitoring and Assessment 147(1-3):83-92

Mahajan, S. and Billore, D. (2014). Assessment of Physico-Chemical characteristics of the Soil of Nagchoon Pond Khandwa, MP, India. Res. J. Chemical Sci. 4(1): 26-30.

Manimegalai, K. and Sukanya, S. (2014). Assessment of Physio-chemical parameters of soil of Muthannan kulam wetland, Coimbatore, Tamilnadu, India. Int. J. Appl. Sci. Biotechnol., 2(3): 302304.

Mendhe, K. (1997). Studies of hydro chemical characters and phytoplankton population of Bilawali Talab Indore, Ph.D. Thesis D.A.V.V. Indore, Madhya Pradesh.

MOEF (1990). Wetlands of India - A directory. Ministry of Environment and Forests, Govt. of India, New Delhi.

Olsen, S.R., Cole, C.V., Watanable, F.S. and Dean, L.A. (1954). Estimation of Available Phosphorus in Soil by Extraction with Sodium bi-carbonate. USDA Circular 939: 1-19.

Paul, A. K. (2000). Wetland ecology principles and conservation. Cambridge: Cambridge University Press, pp. 124238.

Piper, C.S. (1960). Soil and Plant Analysis. The University of Adelaide, Australia.

Rai, S., Chopra, A.K., Pathak, C., Sharma, D.K., Sharma, R. and Gupta, P.M. (2011). Comparative study of some physicochemical parameters of soil irrigated with sew-age water and canal water of Dehradun city, India. Archives Applied Sci. Res. Scholars Res. Lib. 3(2): 318-325.

Reid, W. V, Mooney, H. A., Cropper, A., Capistrano, D., Carpenter, S. R. and Chopra, K. (2005). Ecosystems and Human Well-being: Synthesis. Washington, District of Columbia: Island Press; p. 155.

Richard, L.A. (1968). Diagnosis and improvement of saline and alkali soil. U.S.D.A., Handbook Number 60. Oxford and IBH Publishing Co., NEW DELHI, INDIA.

Saini, D. and Dube, K. K. (2017). Assessment of seasonal variations in physiochemcial parameters to investigate pollution status of Narmada River, Jabalpur region (M.P.). Golbal J. Bio. 
Health Agri. Sci. 6(2):30-33.

Saini, D. and Dube, K. K. (2017). Study of Water Quality of Narmada River, Jabalpur Region (M.P.). Remarking An Analisation. 2(4)72-76.

Shrivastav, A. (1996). Studies on the macrophytic vegetation of Pipalyapala talab, Indore, Ph.D. Thesis, D.A.V.V. Indore, Madhya Pradesh, India

Shrivastav, A. and Thakur, C. S. (2018). Determination of Water quality index by using physico-chemical Properties of various Lake in Jabalpur (M.P.) Int. Res. J. Egi. Tech. 05 (05): 2207-2211.

Singh, P. K. and Shrivastav, P. (2015). Analysis of water quality of river Narmada. Int. J. Current Res. 7(12): 24073-24076.

Subbiah, B.V. and Asija, G.L. (1956). A rapid procedure for the determination of available nitrogen in soils. Current Sci., 25:259-260.
Trivedi, R. K. and Goel, P. K. (1986). Chemical and Biological method for water pollution studies. Environmental publication (Karad, India), 6: 10-12.

Verma and Akhtar (2015). Assessment of Water Pollution in Lakes of Jabalpur. Int. J. Adv. Res. Sci., Engi. Tech. 2(10): 915-922.

Walkley, A. and Black, C.A. (1947). An Examination for Degt Jreff method for determination soil organic matter and proposal for modification of the chromic acid titration method. Soil Sci. 37: 29-38. Wildlife Management, 24: 92-94.

Wang, N., Zhao, G. Y., Lv, Y., and Wu, L. N. (2003). An elementary study on organic and biological contamination in Jin river water of Tianjin. J. Envion. Health 20(5):292-293.

\section{How to cite this article:}

Devendra Podhade, S. B. Lal, Somesh Singh, B. Mehera, Neelam Khare and Abhishek James. 2020. Evaluating the Status of Wetlands of Jabalpur by Soil and Water Quality Analysis. Int.J.Curr.Microbiol.App.Sci. 9(09): 839-849. doi: https://doi.org/10.20546/ijcmas.2020.909.106 